\title{
Newborn screening programmes: Emerging biobanks?
}

\author{
B.M. Knoppers, D. Avard and K. Sénécal \\ Centre of Genomics and Policy (CGP), McGill University, Montreal, Canada \\ Correspondence: Bartha Maria Knoppers, Centre of Genomics and Policy (CGP), McGill University, 740, av. Dr. Penfield, \\ Montreal (Quebec), H3A 1A4, Canada \\ E-mail: bartha.knoppers@mcgill.ca Telephone: (514) 398-8866 Telefax: (514) 398-8954
}

Considered to be in the best interests of the child, in the US alone, 4 million undergo newborn screening each year [1]. In 1994, the US Institute of Medicine (IOM) [2] reiterated the classical WHO criteria [3] for newborn screening programmes: benefit to the newborn, high incidence, availability of effective treatment and sensitivity/specificity of the test [4]. Screening itself is largely mandatory [5]. In 2006, the American College of Medical Genetics recommended the inclusion of an additional 29 core conditions to the classical screening panel, their analysis being made possible by tandem mass spectrometry (multiplex testing) [6].

In newborn screening programmes, a sample of blood is collected from the heel of each baby after birth and then stored. Newborn blood spots (NBS) are stored for variable periods of time to permit either confirmatory diagnosis and re-testing if needed, for test development, or to ensure quality control of the newborn screening programme. Storage and research for these purposes is not particularly controversial since they are related to the primary purpose of the initial collection.

In light of developments fuelled by the completion of the Human Genome project and its accompanying technologies, together with the need for large scale biobanks for genomic research, the storage and use of leftover newborn blood spots have however taken on a new life [7]. At issue are the storage and research uses of residual newborn bloodspots (NBS) for purposes unrelated to the initial collection - finding the asymptomatic at-risk newborn for immediate treatment.

NBS represent a valuable resource for biomedical research, public health surveillance, and sometimes for non-medical purposes, such as identifying disaster victims and for forensic uses. While these latter forensic uses will not be discussed here, they have acquired a certain notoriety and so attracted attention to the banking of NBS [8]. For example, the identification via NBS of the assassin of the Swedish Minister of Foreign Affairs, in Stockholm [9], and the use of NBS following the 2009 Victorian Bushfires Disaster [10,11] (to name but a few publicized cases), drew public attention to the existence of such newborn "banks".

Internationally, newborn screening policies are best characterized as either lacking policies or as inconsistent regarding the storage or research use of NBS and the need to obtain consent or not [1,12]. In 2010, the Institute of Medicine (IOM) specifically addressed the issues surrounding the use of residual newborn screening samples for translational research [13]. Its report underscored concerns about current practices regarding the storage and secondary research uses of newborn bloodspots. It confirmed the need for public policies addressing the management of residual NBS so as to prevent harm either to the parent or child, as well as to the future of this important life saving public health programme.

Yet, the existence of newborn blood spots was largely under the public radar, including that of the parents of newborns, until the first of a series of lawsuits in 2009-2010 in the United States [14,15] and Canada [16]. The underlying rationale for these lawsuits was the fact that the leftover blood spots were stored unbeknownst to parents. Similar arguments were raised across the lawsuits: violation of privacy, failure to obtain a fully informed consent and misrepresentation. As a result, in Texas alone, 5 million dried blood spots were destroyed [14]. Since then, laws and guidelines on the storage and research uses of newborn blood spots are changing in the USA [17-19], Canada [20] and Europe [21-23]. The menace of litigation is one example of how a controversy has policymakers grappling with the potential benefits promised by research using NBS and the public outcry on how newborn bloodspots storage may violate privacy, and forego their right to agree to research.

At the same time, 'biobank' initiatives that collect and store biological samples and various personal information are being created for a number of research purposes (e.g. international consortia such as: www.p3g.org; www.isber.org, and for Europe: www.bbmri.eu). Some biobanks are disease specific such as a tumor repository (e.g. National Cancer Institute [24]), others are from biological material removed during the course of diagnosis or treatment (e.g. American Association of Tissue Banks [25]), and others are longitudinal and populational (e.g. Framingham Heart Study [26]).

Moving forward, can the policies on storage and research used to govern these biobanks be transposed as an alternative solution or as guidance for these inadvertent "newborn biobanks"? We postulate that the ongoing storage and research use of blood spots (I) could effectively place NBS in the situation parallel to those biobanks using residual samples leftover from medical care (II). If so, what recommended changes need to take place in the newborn screening environment to address concerns about informed consent, privacy and misrepresentation? 


\section{NBS: STORAGE AND RESEARCH}

Identifying the issues concerning informed consent, opting out, confidentiality, and ethical oversight as they relate to storage and secondary research is key. Secondary research involves research unrelated to the original purpose of screening program. More specifically, a distinction should be made between the rationale for storing NBS for the benefit of confirming screening results (e.g. false positives are higher in screening), testing new screening methods and performing quality assurance audits, with that of storage for future unspecified research. This is important since, as already mentioned, NBS have been collected under the public health umbrella since the 1960's. Screening an asymptomatic newborn population to find the "at-risk" newborn for treatment occurs in most industrialized countries. Indeed, today such screening forms part of the professional pediatric standard of care [2].

Most policies both at the national, regional and international levels reveal that newborn blood spots are more commonly stored than destroyed [20,23,27-31]. Several guidelines indicate a need to inform parents and community regarding storage and the potential uses of retained blood spots [20,28,29,31,32]. However, in practice, it seems that most parents are not informed about the specific issues surrounding the long term storage of newborn bloodspots [33]. In some countries, newborn blood spots are not stored beyond the period necessary to achieve the tests for which samples were taken as well as for audit and quality assurance $[34,35]$. Periods of retention vary tremendously and run from five years $[23,27]$ to indefinitely [28]. Some countries however, determine storage according to purpose (e.g. Ireland [36]), require that children or adolescents exercise their rights (consent for storage), as soon as they become competent (e.g. Switzerland [37]), or propose retention of bloodspots until children achieve the age of majority at which time consent is sought for further storage (e.g. Sweden [21]). Today, countries are beginning to change their approach regarding storage and research.

\section{Consent}

The storage of residual newborn bloodspots raises consent issues. Some NBS programmes are beginning to treat NBS spots as other residual material collected during medical care. Residual materials generally are used in research without consent if anonymized and subject to ethics review $[21,38,39]$ (see infra, Part II) or, in the case of NBS, if the research is on the screening programme itself $[20,29]$. However, a specific consent for research is often required especially where coded (i.e. linked samples) are to be used [19,27,30,40, 41]. Indeed, when obtaining consent, it is important to state that residual newborn blood spots might be used for disease research or for unspecified future research. Another approach would be to require explicit parental consent for any type of research beyond the confirmatory diagnosis of an affected child [42]. Obviously, withdrawal from any future use of the newborn screening card $[19,27,28,43]$ or to ask for the destruction $[20,29]$ or the return of the NBS card to the family $[20,31]$ are the corollary of consent.

Furthermore, while parents may legally consent on behalf of their children for storage and subsequent research use, some guidelines mention that minors should be asked to reconsent to have their sample stored or used for research when they have sufficient maturity or understanding [21].

\section{Opt-out}

Screening programs exhibit differences regarding the alternatives to an explicit consent for storage and research use of NBS including: notification of research with an opt-out $[19,27,43]$, - a central opt-out register [28], or, notification (before testing) about the storage of bloodspots with presumed participation [32], in the absence of dissent, the blood spot will be retained and used for research [31].

We will see that a few jurisdictions have included storage of bloodspots within the larger context of optout guidelines covering the banking of all residual samples removed during medical care [36] while others have developed new professional guidance on storage and research [31,40] (infra Part II).

\section{Ethical oversight}

Ethical oversight is a key component. Research using NBS should be approved by a research ethics board (REB) and it should be clear whether or not the samples are to be anonymized or coded $[20,28,32,43]$. While the majority of countries still limit research to anonymized samples with only REB approval required, others explicitly state that in addition to such approval, the newborn screening program advisory committee [31] or the scientific advisory board [44] should also have authority over the use of residual blood spots for research.

In summary, proposed reforms concerning research using NBS now range from explicit consent for specific research projects to notification of anonymized research with an opt-out to explicit consent or broad consent for population research. It is interesting to note that some guidelines support having NBS deposited in a national repository that can contribute to health research [40], or that residual blood spots become the property of the State [45].

With these changes, newborn screening programmes have begun to resemble "medical care" biobanks. We shall see that the range of choices offered in NBS are also present in biobanks using residual samples following medical care generally. Indeed, the Secretary's Advisory Committee on Heritable Disorders in Newborns and Children of the USA has stated: "Policymakers should consider the value of the specimens as a promising resource for research, the importance of protecting the privacy and confidentiality of families and the necessity of ensuring the public's trust" [19]. This language echoes the very mission of biobanks. 


\section{NBS AS “BIOBANKS"?}

Before looking at the practices of residual sample biobanks with respect to storage and research so as to examine their parallel with NBS storage and research practices, it would be well to briefly discuss the norms governing biobanks generally. A biobank is: "An organized collection of human biological material and associated information stored for one or more research purposes" [46].

Population biobanks prospectively recruit citizens (presumably asymptomatic) into longitudinal studies and create a resource for future unspecified research using a broad consent [47]. These prospective population studies differ from those biobanks that systematically collect tissue or blood samples leftover (e.g. residual) after their use in medical care and diagnosis [48]. Some examples of residual samples biobanks include Tubafrost [49] in Europe, BBMRI [50] that regroups national residual biobanks in Europe and NCI-OBBR [51] in the USA.

Today, stored NBS collected in newborn screening programmes form part of standard modern pediatric care. If they were to be considered a form of residual sample biobanking, what are the norms governing residual sample biobanks generally and are they adequate for "NBS biobanks"?

The storage and research use of leftover tissues in the clinical setting attracted attention in the 1990's with the beginning of the human genome project. Once considered medical waste and used for approved research without explicit consent, two decades of policy literature on residual samples for research "exceptionalized" their genetic potential. Not only were the biomedical ethics norms governing consent to research applied but genetic information itself was treated differently from other sensitive medical information [52]. This exceptionalist approach has only recently been tempered due to the emergence of two factors: the creation of population biobanks and changes in legislation.

With the completion of the map of the human genome in 2003, attention focused on the meaning of the map and more specifically on the effect of the environment on gene expression. Hence, the need for longitudinal population studies with their emphasis on genotype-phenotype interactions. They recruit asymptomatic citizens who contribute socio-demographic, lifestyle and medical data and biological samples over time with no personal benefit. While the majority of such longitudinal studies recruit randomly and prospectively, certain countries such as Estonia [53], Netherlands [54] and Japan [55] enrol participants during medical care. Again, the objective of the consent to biobanking is clear: to create a data and tissue resource for future unspecified research (usually described as understanding the role of genes in chronic diseases).

More recently however, the research use of residual tissues leftover after medical care is being revisited. In the USA, if such samples are de-identified in such a way that the researcher accessing the samples does not have the key to link back to the code, it is considered non-human subjects research [56] and the regulations on obtaining explicit consent for research do not apply [57]. Likewise, other countries are beginning to consider the research use of residual samples provided for medical care as not only necessary for quality assurance but under a broader public health mandate. Hence, if there is ethics review and approval or proposed research and in-coming patients are properly notified and given the opportunity to opt-out, research use is foreseen without a separate, explicit consent. Indeed, Belgium [38] and the Netherlands [39] treat NBS as other residual samples leftover from children's medical care. More specifically, they do not require specific consent to store and use NBS for research if notification and opt-out options are offered. Moreover, in the Netherlands, a "neonatal heel prick screening steering committee" approves such research [23]. This committee is composed of the various stakeholders including patient organizations. Note that both countries store the samples for a period of 5 years [23,27].

In short, newborn screening now being considered the pediatric professional standard of care, some countries are beginning to apply the same norms that cover the use of residual leftover medical samples for biobanks and research generally, rather than set up a separate regime for NBS. Provided that NBS screening programmes remain centered on treatable or preventable newborn conditions, this may well be a welcome and logical route for NBS storage and research. Will NBS however, follow the example of population biobanks and open up the possibility of moving beyond either an explicit consent or a notification with opt-out approach to the broad consent for future unspecified research used in population biobanks?

\section{CONCLUSION}

The use of tissues such as newborn blood spots is considered critical for medical research advances including for example, identifying various biomarkers [58], validating drug discoveries or, isolating the impact of environmental contaminants [59]. Typically parents are not aware that the NBS are being stored [60,61] and the possibility of requesting to use dried blood spots for research was not mentioned in the educational materials provided to the parents. In the past, the storage and use of newborn blood spots for research received minimal public attention [62]. For families, storage of newborn blood spots and the general lack of information about the exact future purposes of stored samples raise concerns about confidentiality, privacy, and the possible misuses of these samples resulting in psychological harm and discrimination. Research suggests that parents need detailed information if they are to make an informed choice about the use of newborn blood spots [63]. For both NBS and biobanking, it is 
considered good practice to inform patients at the time the samples are collected that the residual bloodspot may be stored and used for research, and a statement to these issues should be provided in a leaflet or on a website. Creating a "Community Values Advisory Committee" [44] or a "BioTrust" [44] is another way to build public trust and foster further discussion between programs and the public.

A review of various policies and laws reveals that there is no general consensus regarding the storage and use of residual NBS for research [1,62,64]. Some jurisdictions such as Sweden have included NBS storage requirements within their laws on biobanking [65]. Overall, the general trend in both NBS and biobanking is towards greater transparency, greater awareness, and a diversity of options from notification with an opt-out for anonymized research, to an explicit consent for specific research projects or broad consent for population studies.

Today, if not undertaken for public health surveillance, REB approval is required for research as this would be considered human subjects research. In NBS, research requests are still largely confined to pediatric conditions. The conditions for NBS storage and re- search need urgent clarification as this new form of "biobank" may soon become the locus of even greater policy challenges when the cost of next generation sequencing becomes affordable for public health programmes.

There is a need to come up with better ways of respecting and balancing individual rights with the common good of public health [66]. If NBS are to be treated as biobanks, parents should at a minimum be notified of storage and of research practices and given the opportunity to opt-out. It is of utmost importance however, that such notification does not affect the participation of parents in the newborn screening programme itself - a public health programme in the best interest of the at-risk, asymptomatic newborn.

\section{ACKNOWLEDGEMENTS}

We acknowledge the financial support of the Canadian Institutes of Health Research (CIHR) for the project "Informing evidence based policy for expanded newborn screening: options for the management of incidental results", and of the Maternal Infant Child \& Youth Research Network (MICYRN). We wish to thank Marissa Figlarz for her valuable work on the references.

\section{REFERENCES}

1. Lewis MH, Goldenberg A, Anderson R, Rothwell E, Botkin J. State laws regarding the retention and use of residual newborn screening blood samples. Pediatrics 2011; 127: 703-12.

2. Andrews LB, Fullarton JE, Holtzman NA, Motulski AG (eds). Assessing genetic risks: implications for health and social policy. Washington, DC: National Academy Press, 1994.

3. Wilson JM, Jungner YG. Principles and practice of mass screening for disease, 1968. http://whqlibdoc. who.int/php/WHO_PHP_34.pdf. Accessed 6 January 2012.

4. Andermann A, Blancquaert I, Beauchamp S, Déry V. Revisiting Wilson and Jungner in the genomic age: a review of screening criteria over the past 40 years. Bull WHO 2008; 86 (4): 317-9.

5. Ross LF. Mandatory versus voluntary consent for newborn screening? Kennedy Inst Ethics J $2010 ; 20$ (4): 299-328.

6. Watson MS, Mann MY, Lloyd-Puryear MA, Rinaldo P, Howell RR. Newborn screening: Toward a uniform screening panel and system - executive summary. Pediatrics 2006; 117 (5): S296.

7. Tarini BA. Storage and use of residual newborn screening blood spots: A public policy emergency. Genet Med 2011; 13 (7): 619.

8. Public Population Project in Genomics (P3G). Population Biobanks Lexicon, 2007. http://www. p3gobservatory.org/download/Biobanks_Lexicon.pdf. Accessed 29 June 2011.

9. Unsgaard E, Meloy JR. The assassination of the Swedish minister for foreign affairs. J Forensic Sci 2011; 56: 555-9.

10. Hartman D, Benton L, Morenos L, Beyer J, Spiden M, Stock A. The importance of Guthrie cards and other medical samples for the direct matching of disaster victims using DNA profiling. Forensic Sci Int 2011; 205 (1-3): 59-63.

11. Hartman D, Drummer O, Eckhoff C, Scheffer J, Stringer P. The contribution of DNA to the disaster victim identification (DVI) effort. Forensic Sci Int 2011; 205 (1-3): 52-8.

12. Kharaboyan L, Avard D, Knoppers BM. Storing newborn blood spots: modern controversies. J Law Med Ethics 2004; 32: 741.

13. Olson S, Berger AC. Challenges and Opportunities in Using Residual Newborn Screening Samples for Translational Research: Workshop Summary. Washington, DC: National Academy Press, 2010.

14. Belono et al. v. Texas Department of State Health Services, 2009.

15. Bearder et al. v. Minnesota et al., 2009.

16. LD (Guardian ad litem of) v. Provincial Health Services Authority, British Columbia, 2011. 
17. Oklahoma State Senate. Unauthorized Storage and Use of DNA from Newborn Without Parental Consent. S 1250. 52nd Legislature. 2nd Regular Session, 2010.

18. Idaho State. IDAPA 16.02.12. http://adm.idaho.gov/adminrules/rules/idapa16/0212.pdf.

19. Secretary's Advisory commitee on Heritable Disorders in Newborns and Children. Briefing Paper - Considerations and Recommendations for National Guidance Regarding the Retention and Use of Residual Dried Blood Spot Specimens after Newborn Screening, 2010. http://www.hrsa.gov/heritabledisorderscommittee/ reports/RBSBriefingPaper0923.pdf. Accessed 29 June 2011.

20. Provincial Health Services Authority (British Columbia-Canada). Storage, Use, Retention and Disposal of Newborn Screening Blood Spot Cards: Policy and Procedure, 2010.

21. Swedish Ministry of Health and Social Affairs. Report: A New Biobank Act (SOU 2010: 81), 2010. http:/ /www.regeringen.se/content/1/c6/15/65/67/d5441333.pdf. Accessed 29 June 2011.

22. German Federal Parliament. Human Genetic Examination Act (Genetic Diagnosis Act - GenDG, 2009. http://www.eurogentest.org/uploads/1247230263295/GenDG_German_English.pdf. Accessed 5 July 2011.

23. Flemish Agency for Care and Health. Vlaams bevolkingsonderzoek naar aangeboren aandoeningen bij pasgeborenen op een bloedstaal, 2010.

24. National Cancer Institute. http://www.cancer.gov/. Accessed 5 July 2011.

25. American Association of Tissue Banks. http://www.aatb.org. Accessed 30 June 2011.

26. Framingham Heart Study. http://www.framinghamheartstudy.org/. Accessed 30 June 2011.

27. The Health Council of the Netherlands. Neonatal Screening, 2005. http://www.gezondheidsraad.nl/sites/ default/files/05@11E.pdf. Accessed29 June 2011.

28. Nørgaard-Pedersen B, Hougaard DM. Storage policies and use of the Danish Newborn Screening Biobank. $J$ Inherit Metab Dis 2007; 30 (4): 530-6.

29. New Zealand Genetic Services - National Testing Centre. Return of newborn metabolic screening samples (Gutherie cards) to family, 2009. http://www.adhb.govt.nz/newborn/Guidelines/Nutrition/ GuthrieCardReturn.pdf. Accessed 29 June 2011.

30. UK Newborn Screening Programme Centre. Newborn Blood Spot Screening in the UK, Policies and Standards, 2005.

31. Human Genetics Society of Australia. Retention, Storage, and Use of Sample Cards from Newborn Screening Programs, 2004. https://www.hgsa.org.au/website/wp-content/uploads/2009/12/2000-P03.pdf. Accessed 29 June 2011.

32. Government of New South Wales - Department of Health. Newborn Bloodspots Screening Policy, 2006. http://www.health.nsw.gov.au/policies/pd/2006/pdf/PD2006_099.pdf. Accessed 29 June 2011.

33. Rothwell EW, Anderson RA, Burbank MJ, et al. Concerns of newborn blood screening advisory committee members regarding storage and use of residual newborn screening blood spots. Am J Public Health 2011; 101: 2111-6.

34. Comité d'éthique - Association française pour le dépistage et la prévention des handicaps de l'enfants. Les prélèvements de sang sur papier pour le dépistage néonatal: recommandations pour leur collecte, leur traitement et leur conservation. Archives de Pédiatrie 1995; 2 (1): 3-7.at.5.

35. Institut national de santé publique du Québec. Rapport d'évaluation du programme québécois de dépistage sanguin des maladies génétiques chez le nouveau-né, 2005. at. 14. http://www.inspq.qc.ca/pdf/publications/ 484-RapportDepistageSanguin.pdf. Accessed 29 June 2011.

36. Irish Council for Bioethics. Human Biological Material: Recommendations for Collection, Use and Storage in Research, 2005. at. 80. http://www.bioethics.ie/uploads/docs/BiologicalMaterial.pdf. Accessed 29 June 2011.

37. Swiss Academy of Medical Sciences (SAMS). Biobanks: Obtainment, preservation and utilisation of human biological material, 2006.

38. Belgian Act (2008). Wet inzake het verkrijgen en het gebruik van menselijk lichaamsmateriaal met hetoog op de geneeskundige toepassing op de mens of het wetenschappelijk onderzoek. As passed by the Parliament of Belgium and given Royal Assent in December 2008.

39. Dutch Civil Code. Burgerlijk Wetboek. s. 7: 467.

40. American College of Medical Genetics. Position Statement on Importance of Residual Newborn Screening Dried Blood Spots, 2009. http://www.acmg.net/StaticContent/NewsReleases/Blood_Spot_Position_ Statement2009.pdf. Accessed 29 June 2011.

41. Australian Government Agency Biotechnology Australia. Genetics in Family Medicine: The Australian Handbook for General Practitioners - Newborn Screening, 2007. http://www.nhmrc.gov.au/_files_nhmrc/file/your_ health/egenetics/GeneticsInFamilyMedicine_WEB.pdf. Accessed 29 June 2011.

42. German National Ethics Council. Opinion Biobanks for Research. http://www.ethikrat.org/_english/ publications/Opinion_Biobanks-for-research.pdf. 2004.

43. UK Newborn Screening Programme Centre (NHS). Code of Practice for the Retention and Storage of Residual Spots, 2005. http://newbornbloodspot.screening.nhs.uk/cms.php?folder=2547. Accessed 29 June 2011. 
44. Chrysler D, McGee H, Bach J, Goldman E, Jacobson PD. The Michigan BioTrust for Health: Using dried bloodspots for research to benefit the community while respecting the individual. $J$ Law Med Ethics 2011; 39: 98-101.

45. Cal. Health and Safety Code $\S 125000$ through 125002 (2008). (www.leginfo.ca.gov/cgi-bin/displaycode? section_hsc\& group_124001-125000\&file_125000-125002).

46. Public Population Project in Genomics (P3G). Population Biobanks Lexicon, 2007. http://www. p3gobservatory.org/download/Biobanks_Lexicon.pdf. Accessed June 292011.

47. Organization for Economic Co-operation and Development. OECD Guidelines on Human Biobanks and Genetic Research Databases, 2009. http://www.oecd.org/dataoecd/41/47/44054609.pdf. Accessed June 29 2011.

48. Knoppers BM. Biobanking: international norms. J Law Med Ethics 2005; 33 (1): 7-14.

49. Tubafrost Central Database - the European Human Tumor Frozen Tissue Bank. http://tubafrost.org/. Accessed 5 July 2011.

50. Riegman PH, van Veen EB. Biobanking residual tissues. Hum Genet 2011; 130: 357-68.

51. National Cancer Institute - Office of Biorepositories and Biospecimen Research. http://biospecimens.cancer. gov/default.asp. Accessed 5 July 2011.

52. Murray TH. Genetic exceptionalism and "future diaries": is genetic information different from other medical information? In: Rothstein M (ed.), Genetic secrets: Protecting privacy and confidentiality in the genetic era. New Haven: Yale University Press 1997: 60-73.

53. Estonia Government. Human Genes Research Act, 2000. http://www.legaltext.ee/text/en/X50010.htm. Accessed 5 July 2011.

54. Stolk RP, et al. Universal risk factors for multifactorial diseases: LifeLines: a three-generation populationbased study. Eur J Epidemiol 2008; 23: 67-74.

55. The BioBank Japan Project on the implication of personalized medicine. http://www.src.riken.jp/english/ project/person/index.html. Accessed 5 July 2011.

56. U.S. Department of Health \& Human Services - Office for Human Research Protection (OHRP). Guidance on Research Involving Coded Private Information of Biological Specimens, 2008. http://www.hhs.gov/ohrp/ policy/cdebiol.pdf. Accessed 5 July 2011.

57. Brothers KB, Clayton EW. " Human non-subjects research": privacy and compliance. AJOB 2010; 10 (9): 15.

58. Poste G. Bring on the biomarkers. Nature 2011; 469 (7329): 156-7.

59. Kapp MB. Ethical and legal issues in research involving human subjects: do you want a piece of me? J Clin Pathol 2006; 59 (4): 335.

60. Olney RS, Moore CA, Ojodu JA, Lindegren ML, Hannon WH. Storage and use of residual dried blood spots from state newborn screening programs. J Pediatr 2006; 148 (5): 618-22.

61. Muchamore I, Morphett L, Barlow-Stewart K. Exploring existing and deliberated community perspectives of newborn screening: informing the development of state and national policy standards in newborn screening and the use of dried blood spots. Aust New Zealand Health Policy 2006; 3 (1): 14.

62. Duquette D, Rafferty A, Fussman C, Gehring J, Meyer S, Bach J. Public support for the use of newborn screening dried blood spots in health research. Public Health Genomics 2011; 14: 143-52.

63. Fant KE, Clark SJ, Kemper AR. Completeness and complexity of information available to parents from newborn-screening programs. Pediatrics 2005; 115 (5): 1268.

64. Avard D, Vallance H, Greenberg C, Laberge C, Kharaboyan L, Plant M. Variability in the storage and use of newborn dried bloodspots in Canada: is it time for national standards? Genomics Soc Policy 2006; 2 (3): 8095.

65. Sweden Government. Ministry of Health and Social Affairs. Biobanks in Medical Care Act (2002: 297), May 23, 2003. http://www.sweden.gov.se/content/1/c6/02/31/26/f69e36fd.pdf. Accessed 5 July 2011.

66. O'Neill O. Broadening bioethics: clinical ethics, public health and global health. $20^{\text {th }}$ Anniversary Nuffield Lecture (unpublished). Delivered at the Royal Society of Arts, 19 May 2011. 